\title{
Antimicrobial activity of ceftriaxone compared with cefotaxime in the presence of serum albumin
}

\author{
SWAPAN K NATH PhD, GARY A FOSTER PhD, LIONEL A MANDELL MD FRCPC, \\ COLEMAN ROTSTEIN MD FRCPC
}

\begin{abstract}
SK NATH, GA Foster, LA MANDELL, C Rotstein. Antimicrobial activity of ceftriaxone compared with cefotaxime in the presence of serum albumin. Can J Infect Dis 1995;6(1):21-27. The effect of serum albumin on the antimicrobial activity of ceftriaxone, cefotaxime, and a 1:1 ratio of cefotaxime and its desacetyl metabolite against nonpseudomonal Gram-negative bacilli was determined. Antimicrobial activity of drugs was evaluated by measuring minimum inhibitory (MIC) and bactericidal (MBC) concentrations in broth with and without human serum albumin. The analysis of logarithmically transformed mean MICS and MBCs showed that there was a highly significant interaction between drug and serum albumin $(P<0.0001)$. The inhibitory and bactericidal activities were greatest for cefotaxime followed by cefotaxime/desacetylcefotaxime and ceftriaxone $(P<0.01)$. Time-kill kinetics demonstrated that ceftriaxone was less bactericidal than cefotaxime in broth with albumin. On the basis of these results it was concluded that the in vitro antimicrobial activity of ceftriaxone compared with that of cefotaxime was significantly diminished in the presence of serum albumin.
\end{abstract}

Key Words: Antimicrobial activity, Cefotaxime, Ceftriaxone, Serum albumin

\section{Activité antimicrobienne du ceftriaxone comparée à celle du céfotaxime en présence d'albumine sérique}

RÉSUMÉ : L'effet de l'albumine sérique sur l'activité antimicrobienne du ceftriaxone, du céfotaxime et d'un ratio 1:1 de céfotaxime et de son métabolite désacétyle contre des bacilles gram négatifs autres que Pseudomonas a été évalué. L'activité antimicrobienne des médicaments a été mesurée à l'aide des concentrations minimales inhibitrices (CMI) et des concentrations bactéricides dans un bouillon de culture avec ou sans albumine sérique humaine. L'analyse des moyennes de Смı et des concentrations bactéricides transformées logarithmiquement a révélé une interaction très significative entre le médicament et l'albumine sérique $(P<0,0001)$. Les activités inhibitrices et bactéricides ont été les plus importantes pour le céfotaxime suivi du céfotaxime/désacétyle céfotaxime et du ceftriaxone $(P<0,01)$. La chronocinétique a démontré que le ceftriaxone était moins bactéricide que le céfotaxime dans le bouillon renfermant de l'albumine. Sur la base de ces résultats, il a été conclu que l'activité antimicrobienne in vitro du ceftriaxone était nettement moindre en présence d'albumine du sérum en comparaison avec celle du céfotaxime.

Department of Laboratory Medicine and Division of Infectious Diseases, Henderson General Hospital, Hamilton, Ontario Correspondence and reprints: Dr SK Nath, Laboratory Medicine, Henderson General Hospital, Hamilton, Ontario L8V 1C3. Telephone (905) 527-4322 ext 2051, Fax (905) 575-2581

Received for publication January 31, 1994. Accepted June 14, 1994 
$\mathrm{T}$ HIRD-GENERATION CEPHALOSPORINS ARE OFTEN USED IN the therapy of serious nosocomial Gram-negative bacterial infections. Ceftriaxone and cefotaxime are similar in antibacterial spectrum and resistance to beta-lactamases, but differ markedly in serum protein binding and elimination half-life (ceftriaxone: $95 \%$ protein bound, elimination half-life of $8.8 \mathrm{~h}$ versus cefotaxime: $35 \%, 1.2 \mathrm{~h})(1,2)$. It has been suggested that serum protein binding may diminish therapeutic efficacy by affecting antibacterial activity and drug distribution (3). Thus, high serum protein binding of ceftriaxone may in fact limit its in vitro activity (4) and impair its therapeutic efficacy compared with that of cefotaxime (5).

In the present investigation, using statistical methods we evaluated differences in the inhibitory and bactericidal activities of ceftriaxone, cefotaxime, and 1:1 combination of cefotaxime and its metabolite desacetylcefotaxime against 121 clinical isolates of nonpseudomonal Gram-negative bacilli in the presence of human serum albumin. Using a time-kill kinetic method we also assessed the diminished killing of organisms by ceftriaxone compared with that of cefotaxime in broth with albumin.

\section{MATERIALS AND METHODS}

One hundred and twenty-one bacteremic isolates of nonpseudomonal Gram-negative bacilli (77 Escherichia coli, 18 Klebsiella pneumoniae, four Klebsiella oxytoca, five Proteus mirabilis, four Citrobacter freundii, nine Enterobacter cloacae and four Enterobacter aerogenes) were used. The isolates were from a stock culture collection, and antimicrobial sensitivities were determined using the MicroScan system (Travenol Laboratories, New Jersey) with break point minimum inhibitory concentration (MICs) in the susceptible category (less than $8 \mu \mathrm{g} / \mathrm{mL}$ ) for both ceftriaxone and cefotaxime. Six other nonpseudomonal Gram-negative bacterial strains (two E coli, two E cloacae and two K pneumoniae) isolated from blood and sputum of patients with pneumonia in an intensive care unit were employed in the study of killing kinetics in broth only and in broth containing $48 \%$ and $95 \%$ equivalent levels of human serum albumin.

Cation-adjusted Mueller-Hinton Broth (CAMHB) (Difco Canada [Lot No G3DXRS]) and nutrient agar (Becton Dickinson BBL Canada [Lot No E4DYYC]) were employed. For each medium, a single batch was used for all in vitro testing.

The antibiotic standard powders employed in the study and their suppliers were: ceftriaxone (Hoffmann-La Roche Ltd [Lot No 12592]); cefotaxime (Hoechst-Roussel Inc [Lot No 112009]); and desacetylcefotaxime (Hoechst-Roussel Inc [Lot No 8A0203B]).

MICs for the organisms were determined by the broth microdilution method (6). Antibiotic stock solutions were prepared according to the manufacturer's instructions. Ceftriaxone, cefotaxime and the 1:1 combination of cefotaxime with its desacetyl metabolite were tested in broth with and without serum albumin using serial doubling dilutions of each antibiotic $(0.015$ to $8 \mathrm{mg} / \mathrm{L})$. Broth with serum albumin contained $19 \mathrm{~g} / \mathrm{L}$ (for time-kill kinetics only) and $38 \mathrm{~g} / \mathrm{L}$ albumin, equivalent to $48 \%$ and $95 \%$ (weight/volume) albumin in
TABLE 1

Susceptibility of nonpseudomonal Gram-negative bacilli $(n=121)$ to ceftriaxone (CAX), cefotaxime (CFT) and cefotaxime/desacetylcefotaxime $(1: 1 ;$ CFT/DACT) in broth only $(0 \%)$ and broth with $95 \%$ equivalent human serum albumin

\begin{tabular}{cccc}
\hline Albumin concentration (\%) & CAX & CFT & CFT/DACT \\
\hline MIC (mg/L): MIC $_{90}$ & & & \\
0 & 0.125 & 0.250 & 0.500 \\
95 & 1.000 & 0.250 & 0.500 \\
MBC (mg/L): MBC $_{90}$ & & & \\
0 & 0.250 & 0.500 & 1.000 \\
95 & 2.000 & 1.000 & 1.000 \\
\hline
\end{tabular}

MBC Minimum bactericidal concentration; MIC Minimum inhibitory concentration

normal human serum. The serum albumin was obtained from blood collected from healthy volunteer donors by the Blood Services of the Canadian Red Cross Society (manufactured and distributed as $25 \%$ solution, USP $100 \mathrm{~mL}$ by Miles Canada Inc). A single batch of serum albumin was used for all in vitro testing. All strains grew in the serum albumin and were included in this study. The drug concentration that finally inhibited growth without any amount of visible growth at higher concentrations was recorded as the MIC after incubation of the panels for $18 \mathrm{~h}$ at $35^{\circ} \mathrm{C}$. Quality control tests were conducted by including E coli ATCC 25922 in each batch of tests. MICs for ceftriaxone and cefotaxime were always found to be within the acceptable ranges.

For minimum bactericidal concentration (MBC) determinations, duplicate $0.01 \mathrm{~mL}$ samples were removed from each well without growth and dispensed by spreading across the surface of nutrient agar plates. Results were recorded after incubation of plates for $18 \mathrm{~h}$ at $35^{\circ} \mathrm{C}$. The initial inocula were determined and ranged from 3 to $4 \times 10^{5}$ colony-forming units $(\mathrm{cfu}) / \mathrm{mL}$. The MBC was defined as the lowest concentration producing at least $99.9 \%$ killing of the original inoculum, using the appropriate rejection values described by Pearson et al (7).

Bactericidal activity of ceftriaxone and cefotaxime against six nonpseudomonal Gram-negative bacteria was also measured using the time-kill kinetic method (8). The antibiotic concentrations that were used represented the MBC for each strain tested. Inoculated broths containing approximately $3.5 \times 10^{5} \mathrm{cfu} / \mathrm{mL}$ and antibiotic were incubated, and at $0,1,2$, $4,6,18$ and $24 \mathrm{~h}$ intervals, a $0.01 \mathrm{~mL}$ aliquot was removed from each of the sample tubes and serially diluted (1:10). A $0.1 \mathrm{~mL}$ of diluent was plated on nutrient agar. Viable counts were determined after incubation of the plates for $18 \mathrm{~h}$ at $35^{\circ} \mathrm{C}$. The bacterial survival measured as $\log _{10} \mathrm{cfu}$ was plotted against time (hours). A time-kill curve was established for each strain. The negative effect of serum albumin on bacterial killing was assessed by a $2 \log _{10}$ or greater increase in cfu (100-fold decrease in killing) at $6 \mathrm{~h}$ instead of $24 \mathrm{~h}$ for the convenience of plotting and extrapolation.

For data analyses, MIC and MBC results less than 0.015 and greater than $8 \mathrm{mg} / \mathrm{L}$ were converted to 0.007 and 16 


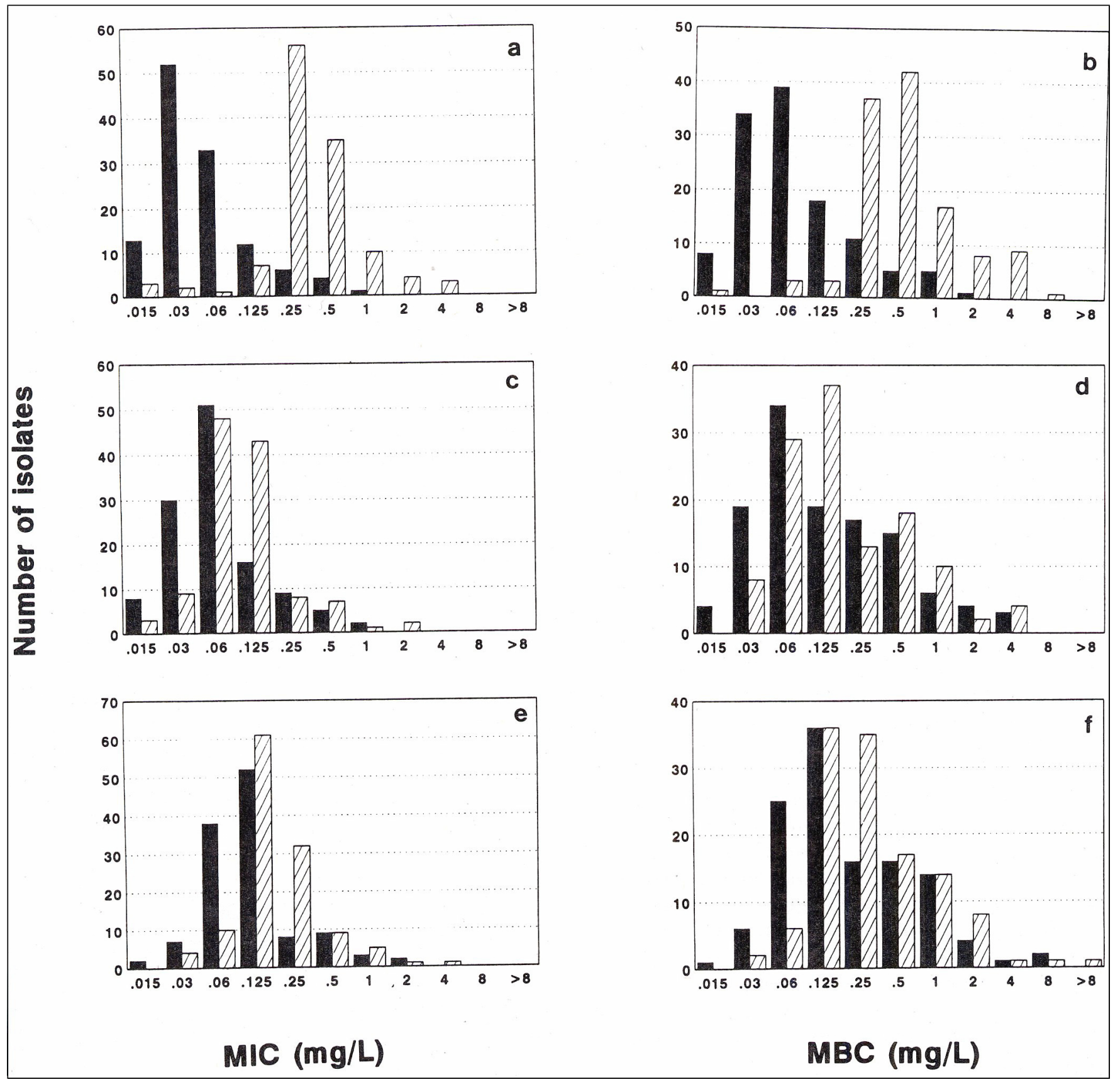

Figure 1) Frequency distribution of minimum inhibitory concentrations (MICs) and minimum bactericidal concentrations (MBCs) (mg/L). All organisms were tested against ceftriaxone (MIC, MBC; a, b), cefotaxime (MIC, MBC; c, d), and cefotaxime/desacetylcefotaxime (MIC, MBC; e, f). Solid bars: in vitro testing in broth without serum albumin; hatched bars: in vitro testing in broth with $95 \%$ equivalent serum albumin

$\mathrm{mg} / \mathrm{L}$. Parametric tests were used to test for differences among the means of the natural logarithmic transformed measurements (ie, geometric means). Two-way analysis of variance (ANOVA) was used to determine whether there was an interaction between antibiotic and serum albumin concentration. One-way ANOVA was used to determine whether there were differences among antibiotics at each of the serum albumin concentrations. When differences occurred, the Scheffé post-hoc test indicated which mean(s) differed significantly from the others.

\section{RESULTS}

The susceptibility data of the bacterial strains in broth and broth with serum albumin are shown in Table 1. A marked effect of serum albumin on the $\mathrm{MIC}_{90}$ and $\mathrm{MBC}_{90}$ was noted. The ceftriaxone $\mathrm{MIC}_{90}$ and $\mathrm{MBC}_{90}$ increased eightfold in the presence of serum albumin. The MIC90 of cefotaxime and cefotaxime/desacetylcefotaxime were virtually unaffected by the addition of serum albumin. There were minor differences in the MBC90 of cefotaxime and cefotaxime/desacetylcefotaxime in broth compared with broth with serum albumin. 
TABLE 2

Statistical analysis of raw data of minimum inhibitory concentrations (MICs) and minimum bactericidal concentrations (MBCs) of ceftriaxone (CAX), cefotaxime (CFT) and cefotaxime/desacetylcefotaxime (1:1; CFT/ DACT) in broth only ( $0 \%$ ) and broth with $95 \%$ equivalent human serum albumin

\begin{tabular}{ccccc}
\hline \multirow{2}{*}{$\begin{array}{l}\text { Albumin } \\
\text { concentration (\%) }\end{array}$} & \multicolumn{4}{c}{ Ceometric mean } \\
\hline MIC (mg/L) & CFT & CFT/DACT & P value* \\
0 & & & & \\
95 & 0.045 & 0.063 & 0.112 & 0.05 \\
MBC (mg/L) & 0.336 & 0.095 & 0.169 & 0.0001 \\
0 & & & & \\
95 & 0.072 & 0.126 & 0.199 & 0.05 \\
\hline
\end{tabular}

${ }^{*}$ Based on the one-way analysis of variance

The frequency (number) distribution for the organisms inhibited (MIC) or killed (MBC) at the antibiotic concentrations are shown in Figure 1. For cefotaxime and cefotaxime/desacetylcefotaxime, the majority of the MIC results were clustered at the three drug concentrations (Figure 1c,e). For ceftriaxone MICS (Figure 1a), the isolates were distributed over two clusters $(0.03$ to $0.06 \mathrm{mg} / \mathrm{L}$ in absence of albumin and 0.25 to 0.5 $\mathrm{mg} / \mathrm{L}$ in presence of albumin). Similar differences are observed for the $M B C$ results of cefotaxime and cefotaxime/desacetylcefotaxime versus ceftriaxone (Figure 1d,f versus $1 \mathrm{~b}$ ). Since the distributions of MIC and MBC raw data were highly skewed, statistical analyses were performed on the geometric means. Two-way ANOVA of MICS and MBCs showed that there was a highly significant interaction between drug and serum albumin $(P<0.0001)$. The extent of this effect was evaluated by one-way ANOVA of MICs tested with the Scheffé post-hoc comparison. There were significant differences in geometric mean MICs and MBCs among the three drugs in broth only $(P=0.05)$ and broth with $95 \%$ equivalent serum albumin $(P=0.0001)$ (Table 2). The one-way ANOVA of MICs with the Scheffé post-hoc comparison definitively showed that cefotaxime and cefotaxime/ desaceytlcefotaxime were significantly more active than ceftriaxone when tested with albumin $(P<0.01)$. Cefotaxime was found to be significantly more inhibitory than a 1:1 combination of cefotaxime and its desacetyl metabolite in broth without and with albumin $(P<0.01)$. Even when serum albumin was added, cefotaxime had the most potent bactericidal activity $(P<0.01)$.

The effects of serum albumin on the bactericidal activity of ceftriaxone and cefotaxime were also assessed by the timekill kinetic analysis. Any reduction in bactericidal activity was assessed by determination of the survival rate $\left(\log _{10} \mathrm{cfu} / \mathrm{mL}\right.$ versus time [hours]) of bacteria when exposed to a drug in broth containing $48 \%$ and $95 \%$ equivalent concentrations of serum albumin. Six strains with elevated MBCs of ceftriaxone were tested: two $E$ coli strains (Figure 2a,b) with ceftriaxone MBCs of 0.03 and $0.125 \mathrm{mg} / \mathrm{L}$ that increased to 0.5 and 2.0 $\mathrm{mg} / \mathrm{L}$, respectively, by addition of serum albumin; two $E$ cloacae strains (Figure 2c,d) with ceftriaxone MBCs of 0.5 and 0.25 $\mathrm{mg} / \mathrm{L}$ that rose to $2.0 \mathrm{mg} / \mathrm{L}$ in broth with serum albumin; and two $K$ pneumoniae strains (Figure $2 \mathrm{e}, \mathrm{f}$ ) with ceftriaxone MBCs of 0.06 and $0.125 \mathrm{mg} / \mathrm{L}$ that increased to 0.5 and $4.0 \mathrm{mg} / \mathrm{L}$ in serum albumin. Only one $K$ pneumoniae strain tested (Figure 2f) had an elevation in cefotaxime MBC (0.03 to $1.0 \mathrm{mg} / \mathrm{L})$. Serum albumin at $48 \%$ or $95 \%$ equivalent serum levels did not overtly affect the bactericidal activity of cefotaxime based on $2 \log _{10}$ or greater increase in survival $(\mathrm{cfu} / \mathrm{mL})$ of bacteria at 6 $\mathrm{h}$ or $24 \mathrm{~h}$. In contrast, a marked negative effect on the bactericidal activity of ceftriaxone was demonstrated for all six strains with the $95 \%$ equivalent serum albumin concentration and for four strains at the $48 \%$ equivalent concentration. There was no difference in the extent of killing at $6 \mathrm{~h}$ or $24 \mathrm{~h}$, when the bactericidal activity of the antibiotics was compared in the presence of $48 \%$ or $95 \%$ equivalent serum albumin.

\section{DISCUSSION}

The relationships between serum protein binding and the distribution of beta-lactam antibiotics has been extensively studied and reviewed over the past two decades (9-19). The differences in serum protein binding between ceftriaxone and cefotaxime have been established $(1,2)$. Methodology has been developed to compare the pharmacokinetics of antibiotics that differ in protein binding (20). Protein binding may be of importance in antibacterial chemotherapy because the bound antibiotic is essentially unavailable for antibacterial activity $(14,21)$. This effect should be reflected by an increase in MIC and $M B C$ under the influence of serum protein. The present study was not intended to quantify the total and free concentrations of ceftriaxone and cefotaxime in serum $(1,2,19)$, but rather to evaluate the change in in vitro inhibitory and, more important, bactericidal activity of ceftriaxone, cefotaxime and ceftotaxime/desacetylcefotaxime (in 1:1 combination) against 121 nonpseudomonal Gram-negative bacteria in the presence of human serum protein. Since ceftriaxone is predominantly bound to albumin (22), the present investigation employed $48 \%$ and $95 \%$ equivalent levels ( 19 and $38 \mathrm{gm} / \mathrm{L}$ ) of human serum albumin, instead of diluting with $25 \%$ or $50 \%$ (volume/volume) of human serum as described by Jones and Barry (4).

We found that MIC90 $(1 \mathrm{mg} / \mathrm{L})$ and $\mathrm{MBC}_{90}(2 \mathrm{mg} / \mathrm{L})$ for ceftriaxone in the presence of $95 \%$ equivalent serum albumin increased eightfold and were at least a twofold dilution lower than those of cefotaxime $(0.25$ and $1 \mathrm{mg} / \mathrm{L})$ and cefotaxime/desacetylcefotaxime ( 0.5 and $1 \mathrm{mg} / \mathrm{L}$ ), respectively. Because the MIC90, a frequently used percentile to evaluate in vitro activity, is prone to error, even in symmetrical data distributions $(23,24)$, and with nonsymmetrical or skewed distributions one should be cautious of using any percentile as an estimator of in vitro activity. We employed the natural logarithmic transformed measurements (ie, geometric means) of MICs and MBCs to achieve a more accurate measure of central tendency $(23,24)$. The geometric mean MIC and MBC were the lowest for ceftriaxone indicating it had the best antimicrobial activity in broth only. However, based on the geometric means, activity of cefotaxime was superior in broth with serum albumin.

Highly significant elevations in the geometric mean MICs 


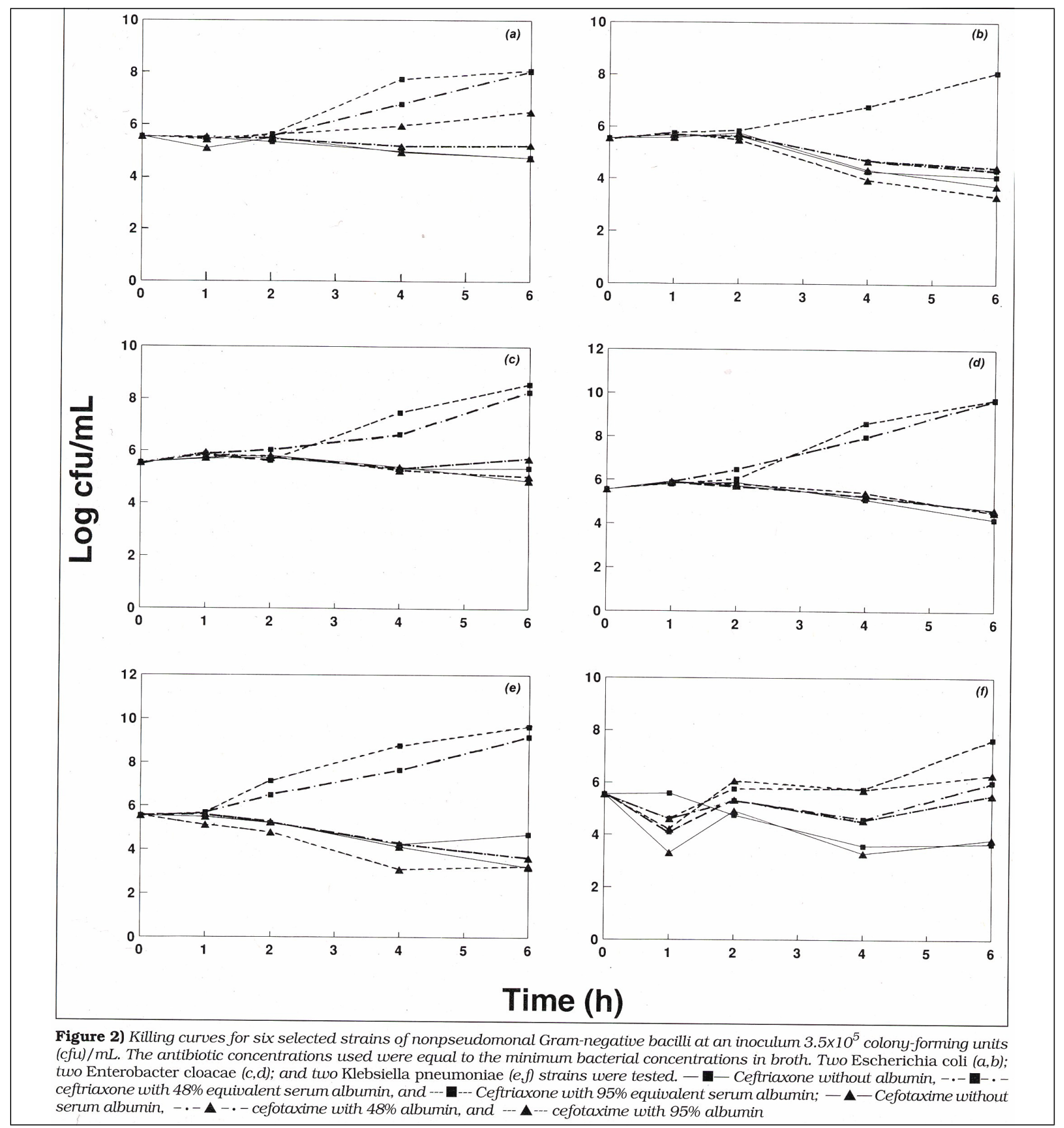

and MBCs of ceftriaxone were observed by two-way ANOVA when in vitro testing was switched from $0 \%$ (broth only) to $95 \%$ equivalent serum albumin. There were also marked differences between cefotaxime and cefotaxime/desacetylcefotaxime. Cefotaxime proved more active than the 1:1 combination of cefotaxime and its metabolite, although an earlier report documented the advantages of antimicrobial agents that have active metabolites (25). Mandell and Afnan (26) also reported synergistic activity of desacetylcefotaxime and its parent compound in the presence of neutrophils. The one-way ANOVA of geometric mean MICs and MBCs tested by Scheffé post-hoc showed that the inhibitory and bactericidal activities were greatest for cefotaxime followed by cefotaxime/desacetylcefotaxime and ceftriaxone.

Because the time-kill kinetic method is considered to be more sensitive than simple MIC-MBC methodology for evaluating antimicrobial activity, it is possible to observe wide differences in the killing kinetics among strains with similar MICs (8). 
Since there was no difference in the extent of killing at 6 or 24 $\mathrm{h}$, the extrapolated results from the convenience plot of $6 \mathrm{~h}$ time-kill tested at $\mathrm{MBC}$ levels of drugs were considered to be predictors of the bactericidal activity. All six strains tested resisted killing by ceftriaxone in broth with $95 \%$ serum albumin. A marked negative effect of serum albumin on the killing by ceftriaxone was also demonstrated for four of six strains at a reduced, $48 \%$ equivalent serum albumin level in the testing broth. The killing rate was also slowed for two of six strains exposed to cefotaxime in broth with serum albumin.

The present study demonstrated a significant reduction in antimicrobial activity of ceftriaxone in the presence of human serum albumin $(P=0.0001)$. In vivo animal model studies such as that of Tawara et al (27) have shown that the therapeutic efficacy of cephem antibiotics including ceftriaxone in $K$ pneumoniae-induced experimental pneumonia correlated with total drug level in serum. However, in a rat model of $K$ pneumoniae pneumonia described by Bakker-Woudenberg et al (28) protein binding of these antimicrobial agents in serum adversely affected both drug penetration into lungs and therapeutic efficacy.

The clinical significance of the negative effect of ceftriaxone binding to serum albumin remains controversial. While the pharmacokinetic and therapeutic efficacy data from the four clinical studies of ceftriaxone and cefotaxime $(5,29-31)$ are equivocal in showing a difference between the two agents, Mandell et al (31) and Smith et al (32) reported that the therapeutic efficacy of ceftriaxone (2 g every $24 \mathrm{~h}$ ) was comparable with that of cefotaxime $(2 \mathrm{~g}$ every $6 \mathrm{~h}$ ) in treating serious nosocomial bacterial infections.

The results of our study suggest that there was a negative influence of serum albumin on the in vitro antimicrobial activity of ceftriaxone. The clinical importance of this has not been determined.

ACKNOWLEDGEMENTS: This study was supported by a grant-inaid from Hoechst-Roussel Canada Inc. The authors acknowledge Gail Filice, RT, for her assistance with all the microbiological and other technical parts of the study.

\section{REFERENCES}

1. Richards DM, Heel RC, Brogden RN, Speight TM, Avery GS. Ceftriaxone: a review of its antibacterial activity, pharmacological properties and therapeutic use. Drugs 1984;27:469-527.

2. Jones RN, Thornsberry C. Cefotaxime, a review of in vitro antimicrobial properties and spectrum of activity. Rev Infect Dis 1982;4(Suppl):301-5.

3. Bergan T, Engeset A, Olszewski W. Does serum protein binding inhibit tissue penetration of antibiotics? Rev Infect Dis 1987;9:713-8.

4. Jones RN, Barry AL. Antimicrobial activity of ceftriaxone, cefotaxime, desacetylcefotaxime, ceftoaximedesacetylcefotaxime in the presence of human serum. Antimicrob Agents Chemother 1987;31:818-20.

5. Reeves JH, Russel GM, Cade JF, McDonald MB. Comparison of ceftriaxone with cefotaxime in serious chest infections. Chest 1989;96:1292-7.

6. National Committee for Clinical Laboratory Standards. Methods for Dilution Antimicrobial Susceptibility Tests for Bacteria that Grow Aerobically, 2nd edn, 1990: Approved Standard M7-A2. Villanova: NCCLS, 1990.
7. Pearson RD, Steigbigel RT, Davis HT, Chapman SW. Methods for reliable determination of minimal lethal antibiotic concentrations. Antimicrob Agents Chemother 1980;18:699-708.

8. Jackson GG, Riff LJ. Pseudomonas bacteremia: pharmacologic and other bases for failure of treatment with gentamicin. J Infect Dis 1971;124(Suppl):185-91.

9. Rolinson GN, Sutherland R. The binding of antibiotics to serum proteins. Br J Pharmacol 1965;25:638-50.

10. Craig WA, Kunin CM. Significance of serum protein and tissue binding of antimicrobial agents. Ann Rev Med 1976;27:287-300.

11. Kunin CM, Craig WA, Kornguth M, Monson R. Influence of binding on the pharmacologic activity of antibiotics. Ann NY Acad Sci 1973;226:214-24.

12. Craig WA, Suh B. Theory and practical impact of binding of antimicrobials to serum proteins and tissue. Scand J Infect Dis 1978;14(Suppl):92-9.

13. Peterson LR, Gerding DN. Influence of protein binding of antibiotics on serum pharmacokinetics and extravascular penetration: clinically useful concepts. Rev Infect Dis 1980;2:340-8.

14. Rolinson GN. The significance of protein binding of antibiotics in antibacterial chemotherapy. J Antimicrob Chermother 1980;6:311-7.

15. Wise R, Gillett AP, Cadge B, Durham SR, Baker S. The influence of protein binding upon tissue fluid levels of six b-lactam antibiotics. J Infect Dis 1980;142:77-82.

16. Gerding DN, Peterson LR. Serum protein binding and extravascular distribution of antimicrobials. J Antimicrob Chemother 1985;15:136-8.

17. Bergan T, Engeset A, Olszewski W, Ostby N, Solberg R. Extravascular penetration of highly protein-bound flucloxacillin. Antimicrob Agents Chemother 1986;30:729-32.

18. Drusano GL. Role of pharmacokinetics in the outcome of infections. Antimicrob Agents Chemother 1988;32:289-97.

19. Scaglione F, Raichi M, Fraschini F. Serum protein binding and extravascular diffusion of methoxyimino cephalosporins. Time courses of free and total concentrations of cefotaxime and ceftriaxone in serum and pleural exudate. J Antimicrob Chemother 1990;26(Suppl A):1-10.

20. Lam YWF, Duroux MH, Gambertoglio JG, Barriere SL, Gugiielmo BJ. Effect of protein binding on serum bacericidal activities of ceftazidime and cefoperazone in healthy volunteers. Antimicrob Agents Chemother 1988;32:298-302.

21. Wise R. Protein binding of b-lactams: the effects on activity and pharmacology particularly tissue penetration. I. J Antimicrob Chemother 1983;12:1-18.

22. Neu HC. Third generation of cephalosporins: safety profiles after 10 years of clinical use. J Clin Pharmacol 1990;30:396-403.

23. White RL, Kays MB, Friedrich LV, Del Bene VE. Impact of different statistical methodologies on the evaluation of the in vitro MICs for Bacteroides fragilis of selected cephalosporins and cephamycins. J Antimicrob Chemother 1993;31:57-64.

24. Davies BI. The importance of the geometric mean MIC. J Antimicrob Chemother 1990;25:471-2.

25. Chin N-X, Neu HC. Cefotaxime and desacetylcefotaxime: an example of advantageous antimicrobial metabolism. Diagnost Microbiol Infect Dis 1984;2(Suppl):21-31.

26. Mandell LA, Afnan M. Synergistic killing of Gram-negative bacilli by cefotaxime, its desacetyl metabolite and human polymorphonuclear neutrophils. J Antimicrob Chemother 1991;27:817-28.

27. Tawara S, Matsumoto S, Kamimura T, Goto S. Effect of protein binding in serum on therapeutic efficacy of cephem antibiotics. Antimicrob Agents Chemother 1992;36:17-24.

28. Bakker-Woudenberg IAJM, Van Den Berg JC, Vree TB, Baars AM, Michel MF. Relevance of serum protein binding of cefoxitin and cefazolin to their activities against Klebsiella pneumoniae in rats. Antimicrob Agents Chemother 1985;28:654-9. 
29. Abbate GF, Alagia I, Giaquinto E, et al. Treatment of lower respiratory infections with ceftriaxone and cefotaxime.

Respiration 1986;49:222-30.

30. Peltola H, Anttila M, Renkonen O-V, the Finnish Study Group. Randomized comparison of chloramphenicol, ampicillin, cefotaxime, and ceftriaxone for childhood bacterial meningitis. Lancet 1989;i:1281-7.
31. Mandell LA, Bergeron MG, Ronald AR, et al. Once-daily therapy with ceftriaxone compared with multi-dose therapy with cefotaxime for serious bacterial infections:

a randomized, double blind study. J Infect Dis 1989;160:433-41.

32. Smith CR, Petty BG, Hendrix CW, et al. Ceftriaxone compared with cefotaxime for serious bacterial infections. J Infect Dis 1989;16:442-97. 


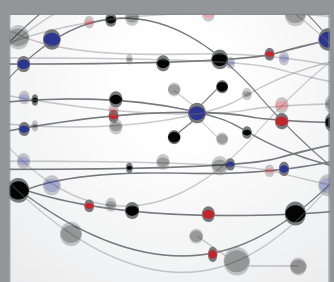

The Scientific World Journal
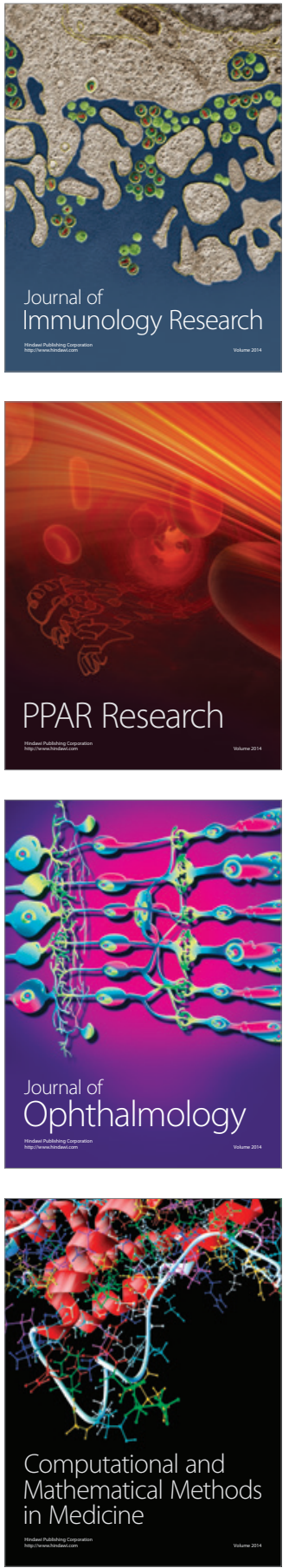

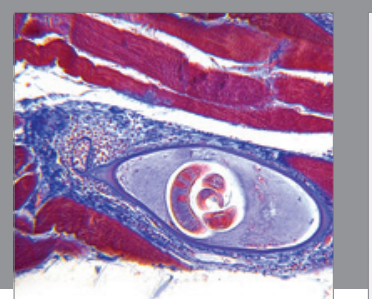

Gastroenterology Research and Practice

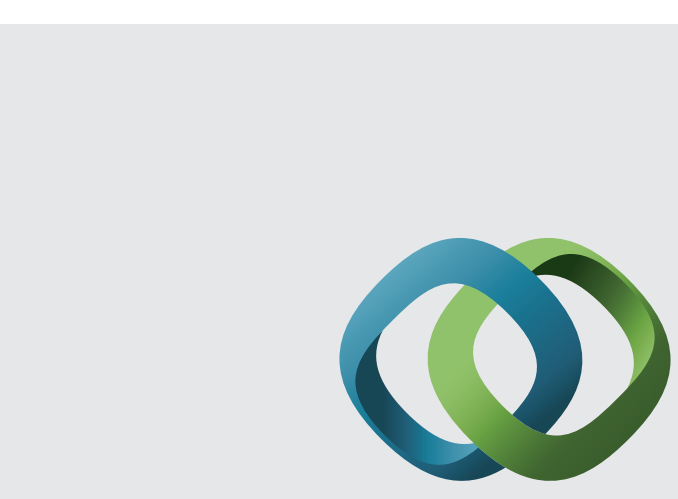

\section{Hindawi}

Submit your manuscripts at

http://www.hindawi.com
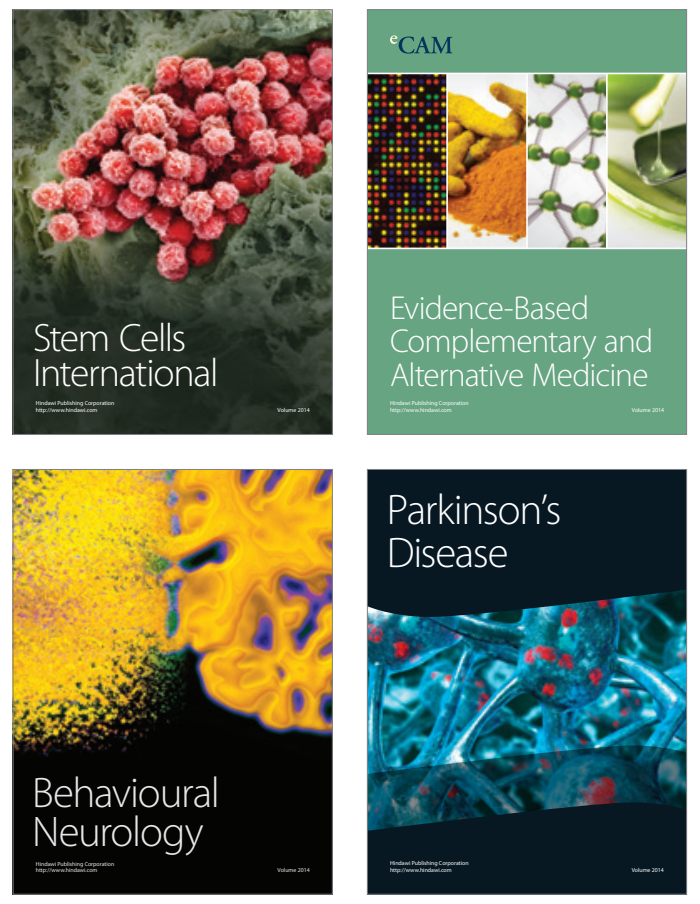
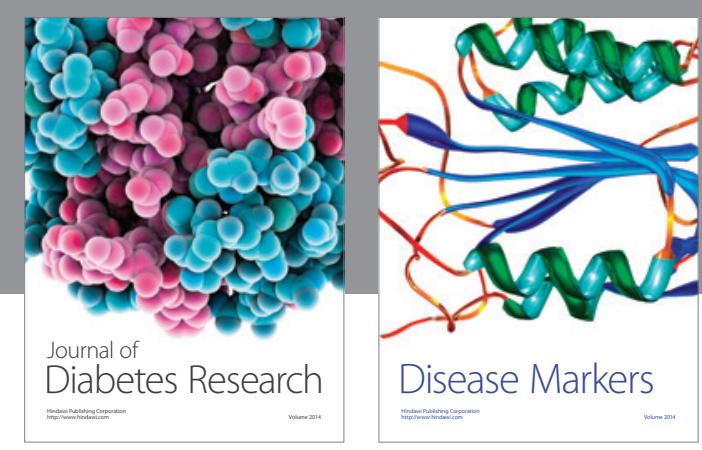

Disease Markers
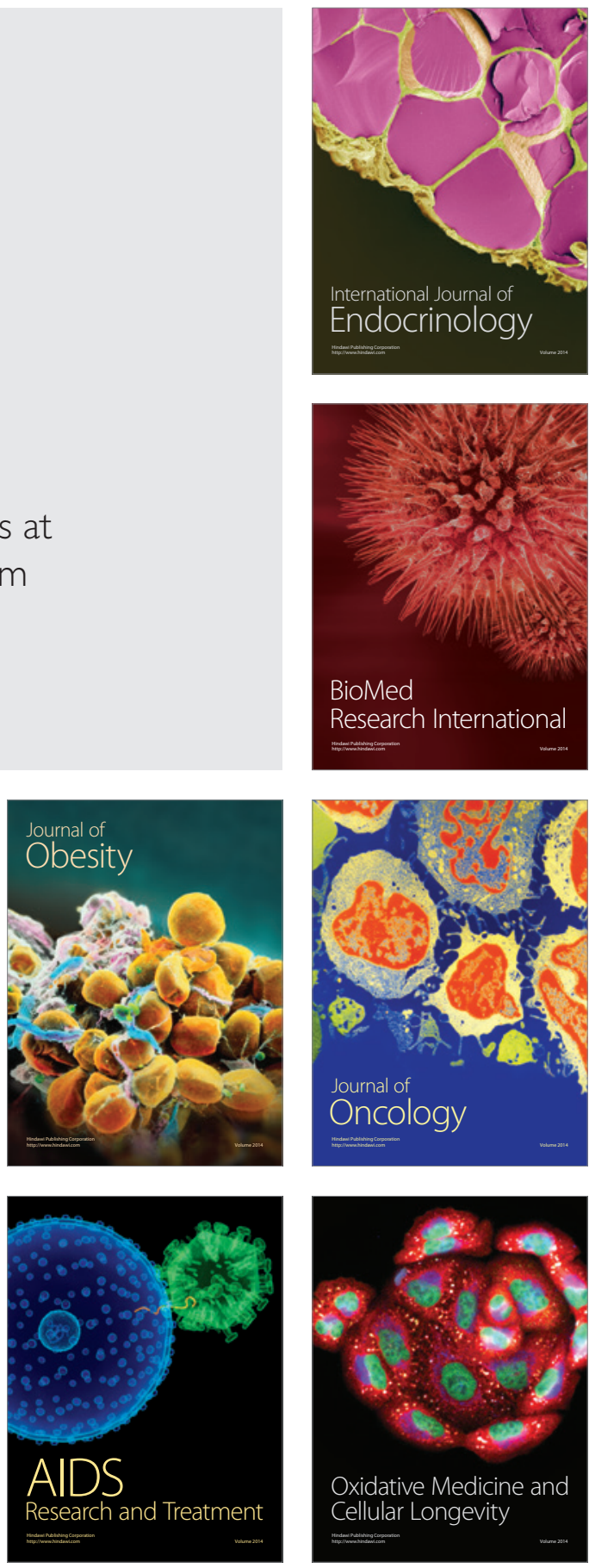